\title{
Fractional uptake of circulating tumor cells into liver-lung compartments during curative resection of periampullary cancer
}

\author{
CAROLINE VILHAV, CECILIA ENGSTRÖM, PETER NAREDI, ANN NOVOTNY, \\ JOHAN BOURGHARDT-FAGMAN, BRITT-MARIE IRESJÖ, ANNIKA G. ASTING and KENT LUNDHOLM \\ Department of Surgery, Institute of Clinical Sciences, Sahlgrenska Academy, \\ University of Gothenburg, Gothenburg SE-41346, Sweden
}

Received April 23, 2018; Accepted August 2, 2018

DOI: $10.3892 / \mathrm{ol} .2018 .9435$

\begin{abstract}
Circulating tumor cells (CTCs) are able to predict outcome in patients with breast, colon and prostate cancer and appear to be promising biomarkers of pancreatic carcinoma. The aim of the present study was to demonstrate a statistically significant portal-arterial difference of CTCs during curative resection of periampullary cancer. A commercially available instrument (Isoflux ${ }^{\mathrm{R}}$ ) was used to quantify blood content of CTC in 10 patients with periampullary cancer according to preoperative diagnostics. Portal and arterial blood samples ( $\sim 8 \mathrm{ml}$ each) were simultaneously collected intra-operatively following surgical dissection prior to division of the pancreas for tumor removal. Quantitative CTC analyses were performed according to standardized protocols for immune-magnetic enrichment of CTC. Flow cytometry was applied for qualitative evaluations of various CTC markers in 7 patients. There was a statistically significant difference in the number of

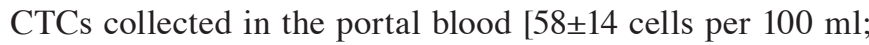
mean \pm standard error (SE)] vs. arterial blood [ $24 \pm 7$ cells per $100 \mathrm{ml}$ (SE), $\mathrm{P}<0.025]$. A fractional uptake of $\geq 40 \%$ across liver and lung compartments of assumed malignant CTC was estimated to correspond to the appearance of $\sim 410$ tumor cells per minute during pancreatic resections based on estimated hepatic blood flow, measured tumor cell mass and tumor cell proliferation activity. Complications in the collection of portal blood were not observed. A significant uptake across liver or lung compartments of potentially malignant tumor CTCs from periampullary carcinoma may represent a model to capture, define and characterize cell clones with metastatic potential in liver and lung tissues following surgical resection.
\end{abstract}

Correspondence to: Professor Kent Lundholm, Department of Surgery, Institute of Clinical Sciences, Sahlgrenska Academy, University of Gothenburg, Blå Stråket 5, Gothenburg SE-41346, Sweden

E-mail: kent.lundholm@surgery.gu.se

Key words: circulating tumor cells, portal blood, periampullary cancer, isoflux, flow cytometry

\section{Introduction}

Pancreatic related cancer is the ninth most common cancer in Western Europe and the fifth common cause of death from cancer (1). The estimated overall 5-year survival in ductal pancreatic carcinoma is less than 5 per cent (2). Hence, there is need for therapy improvements and to understand mechanisms behind metastases to improve postoperative survival of patients with periampullary cancer, since circulating tumor cells (CTC) in patients with gastrointestinal carcinomas are assumed to enter the portal circulation as an initial phase of the metastatic process $(3,4)$. Previous research has indicated numbers of CTC in blood to predict disease prognoses in breast, colon and prostate carcinomas (5-7). There are also indications that CTC may have prognostic value in patients with pancreatic cancer (8-10), suggesting the existence of CTC subgroups with aggressively metastasizing phenotypes $(11,12)$, where increased CTC numbers in portal blood predict liver metastases and reduced survival in pancreatic carcinoma $(13,14)$, and colorectal cancer (15). However, the nature of CTC may be elusive, since cytological characteristics imply similar CTC in both benign and malignant diagnosis (16). Identification and analyses of CTC may despite such uncertainties contribute to facilitate diagnosis; estimate prognosis and better understand the biology of metastases of periampullary carcinoma. Therefore, the aim of the present study was to evaluate methodological possibilities to confirm a statistically significant fractional uptake of CTC across liver-lung compartments during tumor resections aimed at cure in limited number of patients, as a future model for isolation of CTC clones retained across hepatico-lung compartments during surgery.

\section{Materials and methods}

Patients and tumor tissues. Patients $(n=17)$ were included when referred to the Department of Surgery at Sahlgrenska University Hospital and scheduled for pancreatic-duodenal surgery aimed at cure (Whipples operation or total pancreatectomy) due to assumed ductal pancreatic carcinoma or periampullary cancer according to preoperative examinations (Table I). Arterial-portal blood samples from 10 cancer patients were analyzed by Isoflux ${ }^{R}$ to detect and count CTC. Blood samples from additional 7 cancer patients were 
analyzed by flowcytometry (FACS) to evaluate the occurrence of various CTC markers in cancer patients with periampullary tumors. Body weight $[73.8 \pm 16 \mathrm{~kg}$, standard deviation (SD)] and length $(173 \pm 7 \mathrm{~cm}, \mathrm{SD})$ were recorded before operations and used in estimations of liver blood flow compared to expected normal values $\left(1.4-1.5 \mathrm{l} / \mathrm{min} / 1.73 \mathrm{~m}^{2}\right.$ body surface area) (17). All patients were stable during operations; the mean blood loss was $750 \pm 290 \mathrm{ml}(\mathrm{SD})$ and the mean operation time was $359 \pm 56 \mathrm{~min}(\mathrm{SD})$. None of the patients received blood transfusion during operation.

Certified pathologists evaluated tissue biopsy specimens. Postoperative histopathology confirmed 13 adenocarcinomas of the pancreas, 2 bile duct cancers and 2 duodenal cancers. Bile duct cancers are sometimes hard to differentiate from pancreatic carcinoma and may have similar tumor biology. Duodenal cancers may be more diverse perhaps with different characteristics compared to pancreatic adenocarcinoma. Histopathology and the specific origin of periampullary cancer is usually not known until after operations. This explains why our study group represents a mix of different tumors; however, all with epithelial upper gastro-intestinal origin.

Ki-67 analyses (in percent) were performed on resected tumor tissue to achieve estimates of proliferation activity among tumor cells in representative tumor tissue specimens. Tumor tissue mass in the entire resected material was estimated for measurements of tumor volume in three appropriate directions assuming that one $\mathrm{cm}^{3}$ tissue corresponded to one gram wet tissue weight; and that $1 \mathrm{mg}$ tumor tissue wet weight contained approximately $10^{6}$ cells (18), perhaps variable among different kind of tumors (19). The average proportion of tumor cells in tumor tissue was confirmed to be at least 50\% including viability proportion around $80 \%$ based on microscopy. These estimates are used in our attempts to consider flux aspects of blood concentrations of CTC numbers (Discussion).

Blood sampling and CTC analyses. Blood samples were collected after surgical dissections before the removal of the tumor. Blood sampling was performed by direct puncture of the portal vein simultaneously with arterial blood sampling through a catheter in the radial artery inserted before the start of the operation. Complications were not observed related to collection of portal blood in any patient.

Quantification of CTC was performed by commercially available equipment (Isoflux ${ }^{\mathrm{R}}$; Westburg-Fluxion Bioscience Amsterdam, Holland), while qualitative CTC analyses were performed by an in-house Flow cytometric method (FACS), which, however, did not allow quantification of CTC in blood. Samples for Isoflux measurements were from females (60\%) and males (40\%), while samples for FACS were 43 and $57 \%$ from females and males, respectively (Table I). Blood samples were collected in $10 \mathrm{ml}$ syringes $(\sim 8 \mathrm{ml})$ and transferred to special tubes for cell separation (BD Vacutainer CPT sodium heparin/Ficoll). Duplicate samples were collected to confirm that freezing of blood samples before flow cytometric analyses was appropriate. Peripheral venous blood samples were obtained from healthy blood donors for FACS $(n=10)$ analyses.

Blood samples were centrifuged for $20 \mathrm{~min}$ in room temperature at $1,800 \mathrm{xg}$ in a swing-out centrifuge. Cell layer and plasma were transferred to a new tube and washed twice with RPMI (RPMI-1640; Sigma-Aldrich; Merck KGaA,
Darmstadt, Germany), at $300 \mathrm{x}$ g for $10 \mathrm{~min}$ at room temperature. Cell pellets were immediately used for downstream Isoflux analyses. Blood samples for FACS analyses were frozen; cell pellets were resuspended in $400 \mu \mathrm{l}$ fetal bovine serum (FBS; Gibco; Thermo Fisher Scientific, Inc., Waltham, MA, USA), transferred to a cryo tube and diluted with $400 \mu \mathrm{l}$ of 50\% FBS, 30\% RPMI, 20\% DMSO (Gibco; Thermo Fisher Scientific, Inc./Lonza Group, Ltd., Basel, Switzerland/VWR International $\mathrm{GmbH}$, Darmstadt, Germany). Samples were contained in $-80^{\circ} \mathrm{C}$ until use. Frozen cell samples were washed twice with RPMI, centrifuged at $300 \mathrm{x}$ g for $5 \mathrm{~min}$ at room temperatures before downstream analysis by FACS.

Immune-magnetic enrichment of CTCs with isoflux. Immune-magnetic enrichment with Isoflux is a system, where CTC of epithelial origin are captured with different antibodies. The CTC isolation is accomplished with immune-magnetic beads linked to antibodies added to the blood sample targeting markers on the cell surface of the CTC. Through a magnetic field the CTC are then separated from the other blood cells. We used epithelial cellular adhesion molecule (EpCAM) and cytokeratin (CK-7, -8, -18, -19) antibodies for CTC capture and detection by Isoflux; and cluster of differentiation 45 (CD45) antibodies to identify leukocytes. Isoflux has been validated for CTC measurements in cancer patients $(20,21)$. A similar method for CTC enumeration and one of most utilized worldwide is the CellSearch ${ }^{\mathrm{R}}$ system, which applies EpCAM+, CKs+ $(\mathrm{CK}-8,-18,-19)$ and CD45- as standard for CTC detection in breast, colorectal or prostate cancer (22). A difference between Isoflux ${ }^{R}$ and CellSearch ${ }^{R}$ is the use of CK-7 for enrichment of CTC, which seems to be important in periampullary cancer (23) also suggested by the present study (Tables II and IV).

Blood samples from 10 cancer patients were run according to the protocol for the Isoflux equipment provided by the manufacturer (CTC Enrichment kit 630-0124, revision B; Fluxion Biosciences, Alameda, CA, USA). Briefly, cell pellets were immediately resuspended in $200 \mu \mathrm{l}$ RPMI and Fc blocking was added. CTC beads (pre-labeled with EpCAM antibody) were prepared and cell solution transferred to the CTC bead solution. The tubes were rinsed with $300 \mu 1$ binding solution transferred to the bead+CTC solution and incubated for at least $1 \mathrm{~h}$ at rotation in $4^{\circ} \mathrm{C}$. The Isoflux instrument was primed and samples were run according to the protocol for CTC enrichment (version 2; Fluxion Biosciences). Enriched cells were collected in a holder. Collected cells were immediately diluted in binding buffer and enumeration was performed according to Circulating Tumor Cell Enumeration kit (630-0126, revision A; Fluxion Biosciences). Hoechst 33342 dye, anti-CD45+Cy3 and FITC-conjugated anti-Cytokeratin (CK-7, -8, -18 and -19) were used to identify cells, which were counted in a fluorescence microscope (Nikon Eclipse E400; Nikon Corporation, Tokyo, Japan). Cells showing Hoechst+/CD45-/CKs+ staining were regarded as CTC (not shown).

CTC detection by flow cytometry. Each blood sample was divided into 18 different tubes with two different antibodies added to each tube. The total blood volume could not be analyzed together with all antibodies simultaneously, which may fail to identify CTC in tubes without appropriate 
Table I. Diagnosis and tumor stage of patients with cancer. ${ }^{\text {a }}$

\begin{tabular}{|c|c|c|c|c|}
\hline Factor & Age at surgery & Sex & Adenocarcinoma & TNM \\
\hline \multicolumn{5}{|l|}{ Isoflux } \\
\hline 1 & 75 & $\mathrm{~F}$ & Pancreas & T3NOM0 \\
\hline 2 & 59 & $\mathrm{~F}$ & Pancreas & T3N1M1 \\
\hline 3 & 72 & $\mathrm{~F}$ & Pancreas & T3N1M0 \\
\hline 4 & 72 & $\mathrm{~F}$ & Pancreas & T3NOMO \\
\hline 5 & 80 & M & Pancreas & T3N1M0 \\
\hline 6 & 57 & M & Pancreas & $\mathrm{T} 2 \mathrm{~N} 1 \mathrm{M} 0$ \\
\hline 7 & 71 & $\mathrm{~F}$ & Pancreas & T3N1M0 \\
\hline 8 & 75 & $\mathrm{~F}$ & Papillary intestinal & T3N1M0 \\
\hline 9 & 68 & M & Bile ducts & T3N1M0 \\
\hline 10 & 74 & M & Bile ducts & T3N1M0 \\
\hline \multicolumn{5}{|c|}{ Flow cytometry (FACS) } \\
\hline 11 & 74 & M & Duodenum & T4N1M0 \\
\hline 12 & 71 & $\mathrm{~F}$ & Pancreas & T3N1M0 \\
\hline 13 & 77 & M & Pancreas & T3N1M0 \\
\hline 14 & 75 & $\mathrm{~F}$ & Pancreas & T3N1M0 \\
\hline 15 & 72 & $\mathrm{~F}$ & Pancreas & T3N1M0 \\
\hline 16 & 54 & M & Pancreas & T3N1M0 \\
\hline 17 & 37 & M & Pancreas & $\mathrm{T} 1 \mathrm{~N} 1 \mathrm{M} 0$ \\
\hline
\end{tabular}

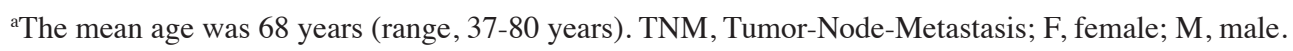

Table II. Number of CTCs detected with immune-magnetic enrichment with isoflux (EpCAM-CKs) in each patient.

\begin{tabular}{lcccc}
\hline Patient & $\begin{array}{c}\text { CTC, amount in } \\
\text { portal sample }\end{array}$ & $\begin{array}{c}\text { CTC, portal } \\
\text { concentration per ml }\end{array}$ & $\begin{array}{c}\text { CTC, amount in } \\
\text { arterial sample }\end{array}$ & $\begin{array}{c}\text { CTC, arterial } \\
\text { concentration per ml }\end{array}$ \\
\hline 1 & 0 & 0 & 0 & 0 \\
2 & 2 & 0.25 & 0 & 0 \\
3 & 6 & 1 & 2 & 0.33 \\
4 & 0 & 0 & 0 & 0 \\
5 & 4 & 0.5 & 2 & 0.25 \\
6 & 10 & 1.25 & 3 & 0.38 \\
7 & 3 & 0.38 & 1 & 0.14 \\
8 & 5 & 0.63 & 1 & 0.2 \\
9 & 8 & 1 & 5 & 0.71 \\
10 & 6 & 0.75 & 3 & 0.38 \\
\hline
\end{tabular}

CTCs, circulating tumor cells.

antibodies. Arterial blood samples from 7 cancer patients and venous blood from 10 healthy individuals were analyzed by flowcytometry (FACS) for the presence of CTC-markers, although our protocol did not allow quantification of the number of marker-positive cells. Cell pellets were resuspended in $1,800 \mu \mathrm{PBS}$, mixed by pipetting and aliquot into 18 tubes. Direct conjugated antibodies [EpCAM FITC/PE (CD326, 130-080-301/130-091-253; Miltenyi Biotec GmbH, Bergisch Gladback, Germany), MIC-A FITC/PE (MCA2403FT; Bio-Rad Laboratories, Inc., Hercules, CA, USA/12-5788-42;
eBioscience; Thermo Fisher Scientific, Inc.), CD133 PE (AC133, 130-080-801; Miltenyi Biotec GmbH), CD34 FITC (BD bioscience 555821), VAP-1 PE (TK8-14, sc-33670; Santa Cruz Biotechnology, Inc., Dallas, TX, USA)] were added including negative controls (BD Biosciences, Franklin Lakes, NJ, USA; Simul test FITC/PE, 382409), and samples were incubated for $30 \mathrm{~min}$ in room temperature. Cells were washed with $1 \mathrm{ml}$ of PBS/BSA 5\% (Sigma-Aldrich; Merck KGaA) and centrifuged at $300 \mathrm{x}$ g for $5 \mathrm{~min}$ at room temperature, resuspended in $200 \mu \mathrm{l}$ PBS and added to a 96-wells plate. $1 \mathrm{ml}$ of 
Table III. CTCs in portal and arterial blood from cancer patients associated with the tumor mass and Ki-67 index of tumor cells.

\begin{tabular}{|c|c|c|c|c|c|c|}
\hline Variable & $\begin{array}{c}\text { Tumor } \\
\text { volume, } \mathrm{cm}^{3}\end{array}$ & $\mathrm{Ki}-67, \%$ & $\begin{array}{l}\text { CTC, amount in } \\
\text { portal samplesc }\end{array}$ & $\begin{array}{l}\mathrm{CTC}, \text { amount in } \\
\text { arterial samples }^{\mathrm{c}}\end{array}$ & $\begin{array}{c}\text { CTC, portal } \\
\text { concentration } \\
\text { per } 100 \mathrm{ml}\end{array}$ & $\begin{array}{c}\text { CTC, arterial } \\
\text { concentration } \\
\text { per } 100 \mathrm{ml}\end{array}$ \\
\hline Patients $(n=10)$ & $26.6 \pm 10.1$ & $17.8 \pm 5.6$ & $4.4 \pm 1.0^{\mathrm{a}}$ & $1.7 \pm 0.5$ & $58 \pm 14^{\mathrm{b}}$ & $24 \pm 7$ \\
\hline
\end{tabular}

There was a statistically significant difference in the number of CTCs collected in the portal blood compared with the arterial blood. Mean \pm standard error of the mean. ${ }^{a} \mathrm{P}<0.05$ vs. CTC amount vs. the amount in arterial sample. ${ }^{b} \mathrm{P}<0.05$ vs. CTC concentration per $100 \mathrm{ml}$ portal blood vs. arterial blood concentration, as determined by analysis of variance. ${ }^{c}$ Mean number of CTCs in collected blood volumes $(\sim 8 \mathrm{ml}$ per sample). CTCs, circulating tumor cells.

Table IV. Results from flow cytometric analyses with expression of markers detected in each blood sample.

\begin{tabular}{|c|c|c|c|c|c|c|c|c|}
\hline $\mathrm{Pt}$ & Blood & EpCAM & MIC-A & CD34 & CD133 & VAP & CK18 & CK19 \\
\hline 11 & Portal & ++ & +++ & - & + & - & - & - \\
\hline 11 & Arterial & ++ & +++ & +++ & ++ & - & - & - \\
\hline 12 & Portal & ++ & +++ & - & ++ & - & - & $+/-$ \\
\hline 12 & Arterial & ++ & +++ & + & ++ & - & - & - \\
\hline 13 & Portal & + & +++ & - & - & - & - & ++ \\
\hline 13 & Arterial & ++ & +++ & - & - & - & - & ++ \\
\hline 14 & Portal & ++ & +++ & + & ++ & - & - & - \\
\hline 14 & Arterial & ++ & +++ & - & ++ & - & - & - \\
\hline 15 & Portal & ++ & +++ & + & ++ & - & - & - \\
\hline 15 & Arterial & ++ & +++ & ++ & ++ & - & - & - \\
\hline 16 & Portal & ++ & +++ & $+/-$ & ++ & - & - & + \\
\hline 16 & Arterial & ++ & +++ & + & ++ & - & - & + \\
\hline 17 & Portal & ++ & +++ & $+/-$ & ++ & - & - & - \\
\hline 17 & Arterial & ++ & +++ & $+/-$ & ++ & - & - & - \\
\hline
\end{tabular}

Pt, patient; +/-, very weak positive or only one of duplicate positive; + , weak positive in the two samples; ++ , positive; +++ , strong positive; ,- negative.

0.1\% Saponin PBS/BSA 5\% (Saponin; Sigma-Aldrich; Merck $\mathrm{KGaA}$ ) was added to 6 tubes for indirect conjugated antibodies (Cytokeratin 18 and 19), and removed by centrifugation at $300 \mathrm{x} \mathrm{g}$ for $5 \mathrm{~min}$ in room temperature. Cytokeratin antibodies were added and samples were incubated for $30 \mathrm{~min}$ at $4^{\circ} \mathrm{C}$. Blank control samples lacked primary antibody. Cells were washed with $1 \mathrm{ml}$ of $0.1 \%$ Saponin PBS/BSA 5\%, centrifuged at $300 \mathrm{x} \mathrm{g}$ for $5 \mathrm{~min}$ at room temperature, secondary antibody (diluted 1:5 in PBS/BSA 5\%) was added and samples were incubated $30 \mathrm{~min}$ at $4^{\circ} \mathrm{C}$. Cells were washed with $1 \mathrm{ml}$ of $0.1 \%$ Saponin PBS/BSA 5\%, centrifuged at $300 \mathrm{x} \mathrm{g}$ for $5 \mathrm{~min}$ at room temperature, resuspended in $200 \mu \mathrm{l}$ PBS and added to a 96-wells plate. Samples were run in FACS guava easyCyte HT (EMD Millipore, Billerica, MA, USA) and analyzed by Guava Software $^{\circledR}$ (EMD Millipore).

Statistical analysis. Results are presented as the mean \pm SD or SEM as indicated. Statistical testing among groups was performed using analysis of variance with Fisher's protected least significant difference post hoc test (Statview 5.0.1; SAS Institute, Inc., Cary, NC, USA). $\mathrm{P}<0.05$ was considered to indicate a statistically significant difference and $\mathrm{P}<0.10$ a trend to significance in two-sided tests.

\section{Results}

Immune-magnetic enrichment of CTC by Isoflux ${ }^{R}$. Portal and arterial blood samples were analyzed in 10 patients with Immune-magnetic enrichment with Isoflux. Ten patients showed between 0 and 5 CTC in arterial blood and between 0 and 10 CTC in portal blood. Seven patients showed CTC in both portal and arterial blood, while two patients showed no CTC in either portal or arterial blood. In one patient CTC was detected in portal blood, but not in arterial blood. Corresponding tissue analyses showed no signs of tumor dissemination to regional lymph nodes in CTC negative patients (Tables I and II). The amount of CTC was significantly higher in portal blood [58 \pm 14 per $100 \mathrm{ml},(\mathrm{SE})]$ compared to arterial blood [24 2 per $100 \mathrm{ml}$, (SE)] equivalent to a fractional uptake of at least $40 \%$ across liver- and lung compartments in patients with periampullary tumors $(\mathrm{P}<0.05$; Table III). Proliferation Ki-67 index was $17.8 \pm 5.6 \%$ (SE) in the tumors (Table III). 

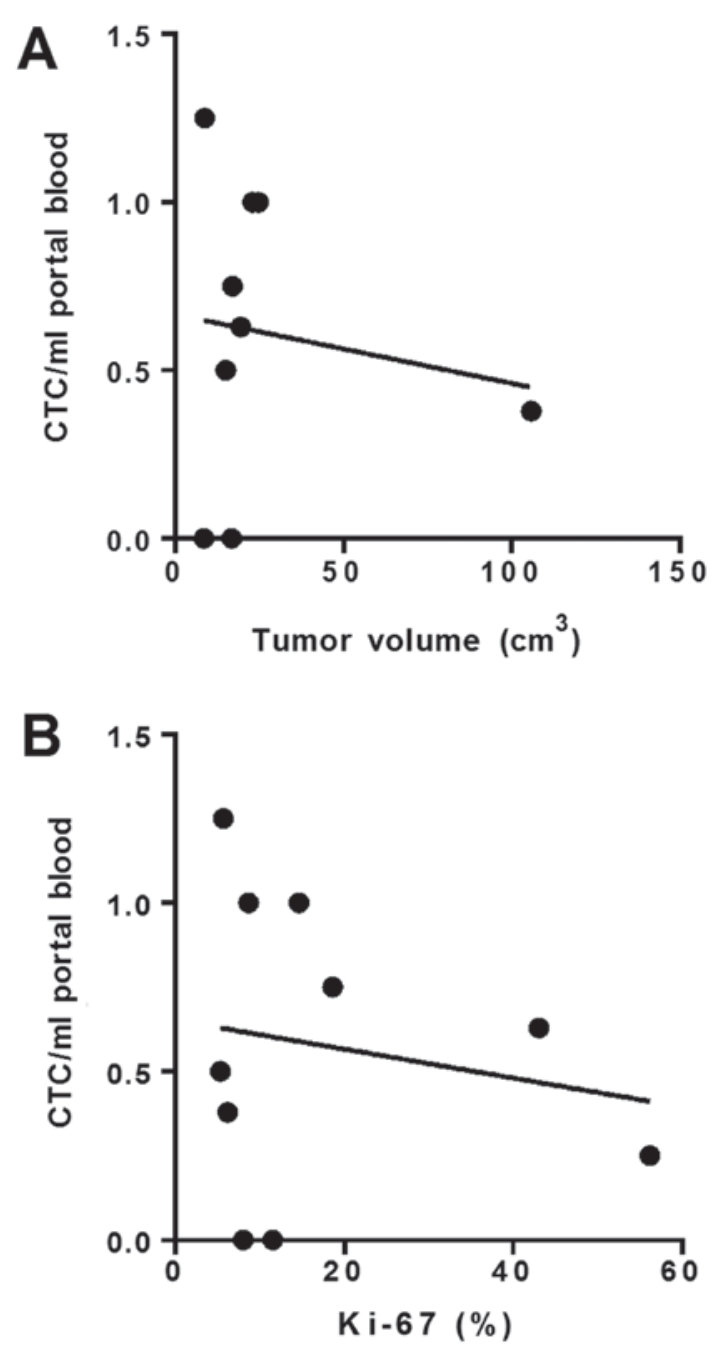

Figure 1. The associations between CTC and (A) tumor volume and (B) Ki-67 in patients with periampullary tumors during curative surgical resection. CTC, circulating tumor cell.

Flow cytometry. Portal and arterial blood were evaluated in 7 cancer patients with FACS. All these patients were positive to MIC-A and EpCAM, in both portal and arterial blood. All patients except one were also positive or weakly positive to CD133 (Table IV). Corresponding histopathology showed tumor dissemination to regional lymph nodes (Table I).

Overall the combination of Isoflux and FACS measurements indicated that present enrichments of CTC from blood were based on highly specific epitopes (cell markers), while our subsequent quantification markers may have been less than optimal. None of our 10 healthy blood donors were positive to any of the markers in FACS analyses (not shown).

\section{Discussion}

The importance of CTC detection has deserved great interest as a possibility to collect liquid tissue samples from patients where direct tissue sampling is difficult. CTC are, however, extremely rare compared to the number of other blood cells, which makes them difficult to identify, count and analyze (24). The validity and relevance of achieved information is thus dependent on the specificity of the markers suggested to be representative for CTC from different tissue origin in a certain condition; i.e., disease stage, treatments etc. In the present investigation CTC were detected by FACS analyses in all investigated blood samples from our cancer patients, positive to EpCAM, MIC-A and CD133, with high specificity, since all individuals in a normal group of blood donors were negative to all applied markers. A combination of markers in a panel may then be recommended in future studies on pancreatic carcinoma. Our FACS analyses confirmed that our applied and fixed markers in the Isoflux platform for immunomagnetic enrichments of CTC were appropriate for quantitative estimates of CTC in the present methodological evaluation.

EpCAM is a protein in the membrane surrounding epithelial cells, contributing to cell adhesion. Epithelial cells are normally not found in the blood circulation. Therefore, EpCAM are considered specific for CTC, since blood cells do not express EpCAM (25). A problem with epithelial-based methods for CTC detection may be epithelial to mesenchymal transition (EMT), since EpCAM may not be expressed at cell surface of CTC when EMT occurs. There is increasing evidence, that EMT is important for increased aggressiveness, metastatic potential and drug resistance in cancers of epithelial origin, including pancreatic cancer (26-28). Thus, EMT may explain falsely low numbers of CTC detected by the Isoflux system in patients. Another circumstance may be that CTC are detected by CK-7, $-8,-18$, and -19 in the Isoflux system. Cytokeratin antibodies $-18,-19$ were applied in our FACS analyses, but found to be negative in most of the samples (Table IV), perhaps due to down regulation of epithelial markers in EMT (29); or to less than standardized methods and optimal biomarkers for CTC detection in pancreatic cancer, although the presence of CK-7 in Isoflux enrichment may be compensatory $(8,23)$. However, significant differences in numbers of cells between portal and arterial blood from the same patients should be less hampered by the use of less than optimal markers, although marker combinations with high sensitivity and specificity should always be strived for in future studies.

CTC in portal blood from patients with pancreatic cancer has been reported earlier $(30,31)$. With the use of a CellSearch ${ }^{\mathrm{R}}$ system, a cutoff amount of 5 CTC or more is utilized to define results as significantly above blank levels, in patients with breast and prostate cancer $(32,33)$, while there is no agreed cut-off level in patients with pancreatic cancer. Again, simultaneous measurements of CTC in portal and arterial blood should make the level of blank cut off levels less critical, but may impact the sensitivity to determine statistical differences in fractional uptake across blood compartments.

False positive results using epithelial markers of CTC are well-recognized in the literature, since antibodies designed for epithelial cells occasionally may stain both hematopoietic and plasma cells (34). Also, non-malignant cells with EpCAM+, $\mathrm{CK}+$ and CD 45-may appear in the circulation of individuals with benign conditions such as inflammation and intestinal polyps (35). Our FACS analyses provided various antibodies with purpose to evaluate the presence of biomarkers in pancreatic cancer, such as MHC class I polypeptide-related sequence A (MIC-A); a stress-inducible glycoprotein expressed as a trans-membrane protein or released as a soluble protein and binding to a receptor expressed in natural killer cells and various T cells. In a variety of epithelial malignancies MIC-A 
expression is increased, including pancreatic cancer, and correlate with the extent of tumor burden $(36,37)$. CD133 is a trans-membrane glycoprotein expressed on the cell surface and found on ductal cells of pancreatic tumors. In earlier studies CD133 expression was significantly associated with lymphatic metastasis and prognosis in pancreatic cancer (38). CD133 is regarded a cancer stem cell marker with evidence that CD133 expression contributes to EMT induction and metastasis in pancreatic cancer $(39,40)$. Thus, optimal combinations of markers for detection and counting of CTC in portal and arterial blood from periampullary cancers remain to be determined.

With all possible limitations in mind we confirmed a statistically significant difference in the amount of CTC in portal-vs. arterial blood with the Isoflux method in a limited number of patients at surgery aimed at cure. This difference indicates that more tumor cells appeared in the portal circulation compared with the level of tumor cells in the arterial compartment where cells are considered to immediate and complete mixing; i.e., the same number of cells in any simultaneously collected arterial blood sample within the body. A portal-arterial difference indicates that CTC appear either from the tumors, as expected, or from any other tissue in the splanchnic bed; or that tumor cells disappear from the circulation across liver-lung compartments; a potential trap for subsequent metastases. This represents a different concept compared to measurements of portal-venous differences $(13,15,30)$, which include a variety of additional tissues as muscles, nerves, bone-marrow among others, that may provide CTC with different tissue origins.

CTC are extremely rare in blood compared to other cells, but in a surgical perspective it may be that time course of CTC appearance in portal blood should predict the intra-and perioperative risk for establishments of hepatic metastases particularly. Therefore, it was interesting to estimate how CTC related to tumor burden. An estimated and assumed average portal blood flow around 1,208 $\mathrm{ml} / \mathrm{min}$ (17); a mean tumor weight of $26.6 \mathrm{~g}$ and a fractional level of at least $50 \%$ tumor cells, with $80 \%$ tumor cell viability (estimated by microscopy) in our tumor tissue specimens, would translate into a viable tumor cell burden in pancreas corresponding to $11^{*} 10^{9}$ cells on average in our patients $\left(26.6 \times 10^{9} \times 0.8 \times 0.5\right)$, since a tumor reaching the size of $1 \mathrm{~cm}^{3}$ (approximately $1 \mathrm{~g}$ wet weight) is usually estimated to contain around $10^{9}$ cells $(18,19)$. This would correspond to an implied appearance rate of $0.59^{*} 10^{6}$

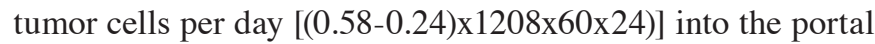
circulation; or corresponding to a tumor mass fraction of $0.005 \%$ per day at operation $\left(0.59 \times 10^{6} / 11 \times 10^{9}\right)$. This implies a low release fraction rate of tumor cells and probably a low efficient process to support metastatic and systemic disease progression considering experimental evidence with less than $2 \%$ of injected tumor cells in experimental liver and lung metastases in mice following bolus and intravenously injected malignant cells (41). Seen together our estimates suggest a risk fraction for metastases at the level of $0.00010 \%$ per day of all CTCs $(0.00005 \times 0.02)$. Thus, it seems that spread of periampullary cancer appears to be a low-efficient process, perhaps in agreement with others suggestion that pancreatic carcinoma has a total disease progression across 20 years, with only late clinical symptoms (42). Our figures equal to a release of approximately 410 CTC per minute during surgical resection and tumor removal, which is a quite new perspective of the risk for per-operative spread during resections.

With above perspectives, it may also be interesting to consider the meaning of $\mathrm{Ki}-67$ proliferation index; i.e., the number of proliferating viable cells in percent of all evaluated tumor cells. Then, the question is the rate unit? Assuming that $26.6 \pm 10 \mathrm{~g}$ of tumor mass with Ki-67 index of $17.8 \pm 5.6 \%$ (Table III), corresponding to net tumor growth during 3 years is equal to $0.97^{*} 10^{7}$ tumor cells per day $\left(26.6 \times 10^{9} \times 0.8 \times 0.5 / 3 \times 365\right)$; which may suggest that the proliferation index has a time unit corresponding to at least 17 days, to be compared to a maximum release of tumor cells into the portal circulation of $0.59 \times 10^{6}$ cells per day $\left[\left(0.97 \times 10^{7}+0.59 \times 10^{6}\right) / 0.59 \times 10^{6}\right]$. This implies that cell cycle rates may be low in pancreatic malignant cells, perhaps in agreement with the lack of correlation between tumor volumes and the release of tumor cells into portal blood (Fig. 1).

In conclusion, the present study applied a ready to use and commercially available instrument (Isoflux ${ }^{\mathrm{R}}$ ) to confirm a statistically significant fractional uptake of presumably malignant cells from periampullary tumors during surgical resections aimed at cure, assessed in a limited number of patients with pancreatic malignancy. This finding may represent a future surgical model to define and characterize tumor cells that disappear across hepatico-lung compartments, which may in part represent tumor clones with high metastatic potential during pancreatic resection. A next step should be to confirm that CTC, retained across the liver or lungs during a first circulation passage, are truly malignant originating from the gastro-intestinal solid tumor.

\section{Acknowledgements}

The authors would like to thank Westburg/Fluxion Bioscience for providing technical support regarding the Isoflux equipment and Director M. Wolving and Mr. S. De Lara, biomedical scientists at the Department of Pathology, Sahlgrenska University Hospital (Gothenburg, Sweden), for providing assistance with complementary tissue analyses. They would also like to thank Dr Christina Biörserud (Department of Surgery, and Gastrosurgical Research and Education, Institute of Clinical Sciences, Sahlgrenska Academy, University of Gothenburg, Gothenburg, Sweden) for providing practical support in the selection of patients.

\section{Funding}

The present study was supported by grants from Cancerfonden (grant nos. 2015/400 and 2017/401) and the Albert Ekmans foundation.

\section{Availability of data and materials}

All data generated or analyzed during this study are included in this published article.

\section{Authors' contributions}

KL and $\mathrm{PN}$ are responsible for the conception and design of the study, as well as obtaining financial support; AA and BI 
were responsible for performing isoflux analyses; AA and AN performed the FACS analyses; $\mathrm{CV}$ and JBF conducted the Ki-67 analyses; CE and CV collected the blood samples, and $\mathrm{CE}$ was in charge of collecting the portal and arterial blood samples during the operations. CV, AA and KL drafted and wrote the manuscript. All authors participated in revising the manuscript.

\section{Ethics approval and consent to participate}

The Regional Ethical Review Board of Gothenburg approved the present study (462-11) and all participants provided written informed consent.

\section{Patient consent for publication}

Not applicable.

\section{Competing interests}

The authors declare that they have no competing interests.

\section{References}

1. Ferlay J, Steliarova-Foucher E, Lortet-Tieulent J, Rosso S, Coebergh JW, Comber H, Forman D and Bray F: Cancer incidence and mortality patterns in Europe: Estimates for 40 countries in 2012. Eur J Cancer 49: 1374-1403, 2013.

2. Ferlay J, Soerjomataram I, Dikshit R, Eser S, Mathers C, Rebelo M, Parkin DM, Forman D and Bray F: Cancer incidence and mortality worldwide: Sources, methods and major patterns in GLOBOCAN 2012. Int J Cancer 136: E359-E386, 2015.

3. Azevedo AS, Follain G, Patthabhiraman S, Harlepp S and Goetz JG: Metastasis of circulating tumor cells: Favorable soil or suitable biomechanics, or both? Cell Adh Migr 9: 345-356, 2015.

4. Rhim AD, Mirek ET, Aiello NM, Maitra A, Bailey JM, McAllister F, Reichert M, Beatty GL, Rustgi AK, Vonderheide RH, et al: EMT and dissemination precede pancreatic tumor formation. Cell 148: 349-361, 2012.

5. Giuliano M, Giordano A, Jackson S, De Giorgi U, Mego M, Cohen EN, Gao H, Anfossi S, Handy BC, Ueno NT, et al Circulating tumor cells as early predictors of metastatic spread in breast cancer patients with limited metastatic dissemination. Breast Cancer Res 16: 440, 2014.

6. Iinuma H, Watanabe T, Mimori K, Adachi M, Hayashi N, Tamura J, Matsuda K, Fukushima R, Okinaga K, Sasako M and Mori M: Clinical significance of circulating tumor cells, including cancer stem-like cells, in peripheral blood for recurrence and prognosis in patients with Dukes' stage B and C colorectal cancer. J Clin Oncol 29: 1547-1555, 2011.

7. Thalgott M, Heck MM, Eiber M, Souvatzoglou M, Hatzichristodoulou G, Kehl V, Krause BJ, Rack B, Retz M, Gschwend JE, et al: Circulating tumor cells versus objective response assessment predicting survival in metastatic castration-resistant prostate cancer patients treated with docetaxel chemotherapy. J Cancer Res Clin Oncol 141: 1457-1464, 2015.

8. Tjensvoll K, Nordgård O and Smaaland R: Circulating tumor cells in pancreatic cancer patients: Methods of detection and clinical implications. Int J Cancer 134: 1-8, 2014.

9. Okubo K, Uenosono Y, Arigami T, Mataki Y, Matsushita D, Yanagita S, Kurahara H, Sakoda M, Kijima Y, Maemura K and Natsugoe S: Clinical impact of circulating tumor cells and therapy response in pancreatic cancer. Eur J Surg Oncol 43: 1050-1055, 2017.

10. Xie ZB, Yao L, Jin C and Fu DL: Circulating tumor cells in pancreatic cancer patients: Efficacy in diagnosis and value in prognosis. Discov Med 22: 121-128, 2016.

11. Barriere G, Riouallon A, Renaudie J, Tartary M and Rigaud M: Mesenchymal characterization: Alternative to simple CTC detection in two clinical trials. Anticancer Res 32: 3363-3369, 2012.
12. Yu M, Bardia A, Wittner BS, Stott SL, Smas ME, Ting DT, Isakoff SJ, Ciciliano JC, Wells MN, Shah AM, et al: Circulating breast tumor cells exhibit dynamic changes in epithelial and mesenchymal composition. Science 339: 580-584, 2013.

13. Arnoletti JP, Zhu X, Almodovar AJ, Veldhuis PP, Sause R, Griffith E, Corpus G, Chang JC, Fanaian N and Litherland SA: Portal venous blood circulation supports immunosuppressive environment and pancreatic cancer circulating tumor cell activation. Pancreas 46: 116-123, 2017.

14. Tien YW, Kuo HC, Ho BI, Chang MC, Chang YT, Cheng MF, Chen HL, Liang TY, Wang CF, Huang CY, et al: A high circulating tumor cell count in portal vein predicts liver metastasis from periampullary or pancreatic cancer: A high portal venous CTC count predicts liver metastases. Medicine (Baltimore) 95: e3407, 2016.

15. Connor AA, McNamara K, Al-Sukhni E, Diskin J, Chan D, Ash C, Lowes LE, Allan AL, Zogopoulos G, Moulton CA and Gallinger S: Central, but not peripheral, circulating tumor cells are prognostic in patients undergoing resection of colorectal cancer liver metastases. Ann Surg Oncol 23: 2168-2175, 2016.

16. Rosenbaum MW, Cauley CE, Kulemann B, Liss AS, Castillo CF, Warshaw AL, Lillemoe KD, Thayer SP and Pitman MB: Cytologic characteristics of circulating epithelioid cells in pancreatic disease. Cancer Cytopathol 125: 332-340, 2017.

17. Bradley SE, Ingelfinger FJ, Bradley GP and Curry JJ: The estimation of hepatic blood flow in man. J Clin Invest 24: 890-897, 1945.

18. DeVita VT Jr, Young RC and Canellos GP: Combination versus single agent chemotherapy: A review of the basis for selection of drug treatment of cancer. Cancer 35: 98-110, 1975.

19. Del Monte U: Does the cell number 10(9) still really fit one gram of tumor tissue? Cell Cycle 8: 505-506, 2009.

20. Harb W, Fan A, Tran T, Danila DC, Keys D, Schwartz M and Ionescu-Zanetti C: Mutational analysis of circulating tumor cells using a novel microfluidic collection device and qPCR assay. Transl Oncol 6: 528-538, 2013

21. Xu L, Mao X, Imrali A, Syed F, Mutsvangwa K, Berney D, Cathcart P, Hines J, Shamash J and Lu YJ: Optimization and evaluation of a novel size based circulating tumor cell isolation system. PLoS One 10: e0138032, 2015.

22. Miller MC, Doyle GV and Terstappen LW: Significance of circulating tumor cells detected by the CellSearch system in patients with metastatic breast colorectal and prostate cancer. J Oncol 2010: 617421, 2010.

23. Goldstein NS and Bassi D: Cytokeratins 7, 17 and 20 reactivity in pancreatic and ampulla of vater adenocarcinomas. Percentage of positivity and distribution is affected by the cut-point threshold. Am J Clin Pathol 115: 695-702, 2001.

24. Joosse SA and Pantel K: Biologic challenges in the detection of circulating tumor cells. Cancer Res 73: 8-11, 2013.

25. Munz M, Baeuerle PA and Gires O: The emerging role of EpCAM in cancer and stem cell signaling. Cancer Res 69: 5627-5629, 2009.

26. Arumugam T, Ramachandran V, Fournier KF, Wang $\mathrm{H}$, Marquis L, Abbruzzese JL, Gallick GE, Logsdon CD, McConkey DJ and Choi W: Epithelial to mesenchymal transition contributes to drug resistance in pancreatic cancer. Cancer Res 69: 5820-5828, 2009.

27. Shah AN, Summy JM, Zhang J, Park SI, Parikh NU and Gallick GE: Development and characterization of gemcitabine-resistant pancreatic tumor cells. Ann Surg Oncol 14: 3629-3637, 2007.

28. Boyer B, Vallés AM and Edme N: Induction and regulation of epithelial-mesenchymal transitions. Biochem Pharmacol 60: 1091-1099, 2000.

29. Wu S, Liu S, Liu Z, Huang J, Pu X, Li J, Yang D, Deng H, Yang $\mathrm{N}$ and $\mathrm{Xu} \mathrm{J}$ : Classification of circulating tumor cells by epithelial-mesenchymal transition markers. PLoS One 10: e0123976, 2015.

30. Bissolati M, Sandri MT, Burtulo G, Zorzino L, Balzano G and Braga M: Portal vein-circulating tumor cells predict liver metastases in patients with resectable pancreatic cancer. Tumour Biol 36: 991-996, 2015.

31. Catenacci DV, Chapman CG, Xu P, Koons A, Konda VJ, Siddiqui UD and Waxman I: Acquisition of portal venous circulating tumor cells from patients with pancreaticobiliary cancers by endoscopic ultrasound. Gastroenterology 149: 1794-1803.e4, 2015. 
32. Jiang ZF, Cristofanilli M, Shao ZM, Tong ZS, Song EW, Wang XJ, Liao N, Hu XC, Liu Y, Wang Y, et al: Circulating tumor cells predict progression-free and overall survival in Chinese patients with metastatic breast cancer, HER2-positive or triple-negative (CBCSG004): A multicenter, double-blind, prospective trial. Ann Oncol 24: 2766-2772, 2013.

33. Shaffer DR, Leversha MA, Danila DC, Lin O Gonzalez-Espinoza R, Gu B, Anand A, Smith K, Maslak P, Doyle GV, et al: Circulating tumor cell analysis in patients with progressive castration-resistant prostate cancer. Clin Cancer Res 13: 2023-2029, 2007.

34. Mavroudis D: Circulating cancer cells. Ann Oncol 21 (Suppl 7): vii95-vii100, 2010

35. Pantel K, Deneve E, Nocca D, Coffy A, Vendrell JP, Maudelonde T, Riethdorf $S$ and Alix-Panabières $C$ : Circulating epithelial cells in patients with benign colon diseases. Clin Chem 58: 936-940, 2012.

36. Dambrauskas Z, Svensson H, Joshi M, Hyltander A, Naredi P and Iresjö BM: Expression of major histocompatibility complex class I-related chain A/B (MICA/B) in pancreatic carcinoma. Int J Oncol 44: 99-104, 2014

37. Xu X, Rao GS, Groh V, Spies T, Gattuso P, Kaufman HL, Plate J and Prinz RA: Major histocompatibility complex class I-related chain A/B (MICA/B) expression in tumor tissue and serum of pancreatic cancer: Role of uric acid accumulation in gemcitabine-induced MICA/B expression. BMC Cancer 11: 194, 2011.
38. Maeda S, Shinchi H, Kurahara H, Mataki Y, Maemura K, Sato M, Natsugoe S, Aikou T and Takao S: CD133 expression is correlated with lymph node metastasis and vascular endothelial growth factor- $\mathrm{C}$ expression in pancreatic cancer. $\mathrm{Br} \mathrm{J}$ Cancer 98: 1389-1397, 2008.

39. Nomura A, Banerjee S, Chugh R, Dudeja V, Yamamoto M, Vickers SM and Saluja AK: CD133 initiates tumors, induces epithelial-mesenchymal transition and increases metastasis in pancreatic cancer. Oncotarget 6: 8313-8322, 2015.

40. Ding Q, Miyazaki Y, Tsukasa K, Matsubara S, Yoshimitsu M and Takao S: CD133 facilitates epithelial-mesenchymal transition through interaction with the ERK pathway in pancreatic cancer metastasis. Mol Cancer 13: 15, 2014

41. Fidler IJ: Tumor heterogeneity and the biology of cancer invasion and metastasis. Cancer Res 38: 2651-2660, 1978.

42. Yachida S, Jones S, Bozic I, Antal T, Leary R, Fu B, Kamiyama M, Hruban RH, Eshleman JR, Nowak MA, et al: Distant metastasis occurs late during the genetic evolution of pancreatic cancer. Nature 467: 1114-1117, 2010.

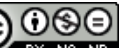

This work is licensed under a Creative Commons Attribution-NonCommercial-NoDerivatives 4.0 International (CC BY-NC-ND 4.0) License. 